\title{
Developing a Framework for Infrastructure \& Facility Asset Management Knowledge \& Science Development by Using Concept Mapping
}

\author{
Menyusun Kerangka Kerja bagi Pengembangan Ilmu Pengetahuan \\ Manajemen Aset Infrastruktur \& Fasilitas dengan Menggunakan \\ Pemetaan Konsep
}

\author{
Hitapriya Suprayitno ${ }^{1, a}$ \& Ria Asih Aryani Soemitro ${ }^{1, b}$ \\ ${ }^{1}$ Civil Engineering Department, Institut Teknologi Sepuluh Nopember (ITS), Surabaya. \\ Correspondent : ${ }^{a}$ suprayitno.hita@gmail.com \& bsoemitroraa@gmail.com
}

\begin{abstract}
Infrastructure and Facility are capital for region's life. Therefore, Infrastructure \& Facility Asset Management Knowledge must be developed and implemented. Jurnal Manajemen Aset Infrastruktur \& Fasilitas was established for developing this. The development needs a framework. A Knowledge Development Framework has been thought and formulated. The framework is presented by concept mapping. It consists of an Infrastructure \& Facility Asset Management Conceptual Model, an Infrastructure \& Facility Asset Management Basic Model and 6 Basic Knowledges. The 6 Basic Knowledges are about : the Infrastructure \& Facility, Infrastructure \& Facility Managing Organization, Infrastrucutre \& Facility Asset Management, Organization Management, Tools for Analyses, and Related Software can be used for Asset Management.
\end{abstract}

Keyword : infrastructure \& facility asset management, knowledge development framework

\section{INTRODUCTION}

It is already a general understanding that Infrastructures and Facilities (I\&F) are capital for region's and national's life. The I\&F is a pre-requisite for development. Meanwhile, it can be understood easily that I\&F are not simple object. It must be constructed, practically all are onerous and technically can be very complex. Therefore the existence and the function performance must be guarded to be sustainable, economic, efficient and effective. Shortly, the I\&F must be well managed. Therefore, I\&F Asset Management (I\&FAM) is important (Soemitro \& Suprayitno 2018; Suprayitno \& Soemitro 2018).

It is clear that, the I\&FAM Knowledge need to be developed. Jurnal Manajemen Aset Infrastruktur \& Fasilitas (JMAIF) is founded for developing science and knowledge of I\&FAM. A Framework for I\&FAM Knowledge Development need to be formulated to guide the Knowledge Development direction and mapping. The main questions for developing the framework are : what is I\&FAM, what are the knoweledge components, how these should be modeled.

This paper present an attempt to develop the knowledge structure in order to able to well develop I\&FAM Knowledge Development Framework.

\section{RESEARCH METHOD}


The research was executed by following stepss : background description, objective statement, literature review, framework development, and finalized by conclusion. A special method, the concept mapping, was used completed by narrative explanation.

\section{LITERATURE REVIEW}

I\&FAM is a program and knowledge to manage the $I \& F$, for the $I \& F$ can sustainably perform its function well, economically, efficiently, effectively, and still within the principle of green (environmentally, socialy, economicaly) (Soemitro \& Suprayitno 2018; Suprayitno \& Soemitro 2018).

Framework is a guidance or a terms of reference to do something. The framework must expressed the direction, the components and the limitation of the work will be executed. The relation and the corelation mechanism among components must be expressed also. The framework can be presented in narrative form or in concept mapping form (Wikipedia 2018b; Wikipedia 2018c).

The word mapping is always automatically associated with geographical mapping. In fact the word mapping is also used to denote mind mapping, concept mapping and the others. The word mapping denote "knowledge visualization". With visualization, knowledge construct will be presented more clear and easier to be understood. The literature review discuss only geographical mapping, concept mapping and mind mapping. Geographical Mapping is putting information or data into a geographical map. Geographical Information System (GIS) is a software for Geographical Mapping. Concept Mapping is a technique to represent an idea in visual diagram. Representation is done by using a network of a concept, each represented by a box or a circle related each other with arrow or line, depend on the existence of its correlation. Mind Mapping is a way to represent idea or concepts in a picture form. Focusing on key ideas and looking for links among each key ideas. In fact concept mapping and mind mapping is very similar (Eppler 2006; FacDev 2010; Learning Support 2010)..

\section{FRAMEWORK DEVELOPMENT}

\section{Terms of Reference for Framework Development}

The I\&FAM Knowledge Development Framework must be simple enough, must be very easy to be understood, must be grouped in several level as needed, must be construted based on concept mapping.

\section{Infrastructure \& Facility Asset Management}

I\&FAM is the science, the knowledge or the acts in managing the infrastructure and facility, in order that the infrastructure and the facility to be able to function sustainably well, in economic way, efficiently, effectivly and respect the Sustainability Principle (socially, economically, environmentally) (Soemitro \& Suprayitno 2018; Suprayitno \& Soemitro 2018).

\section{I\&FAM Knowledge Structure Mapping}

For the purpose of knowledge structure mapping, here the I\&FAM Knowledges are grouped into several following components : asset management, I\&FAM, I\&F, managing organization, infrastructure asset management, organization management, and tools for analyse.

\section{What is Asset Management}

Asset management is systematic approach for managing assets in order that the assets value can always grow sustainably or the assets is always capable to perform its function sustainably. Physical Assets Management practically deals with procurement, operating, 
maintaining and disposing asset in cost-effective way, to reach the maximum of its function (Wikipedia 2018).

\section{What is I\&FAM - Basic Conceptual Model}

I\&FAM is programs or knowledge to manage physical assets : infrastructure and facility. In general, the I\&FAM consists of knowledges on the I\&F itself, the I\&F Managing Organization, the I\&FAM and the Organization Management (Soemitro \& Suprayitno 2018; Suprayitno \& Soemitro 2018; Wikipedia 2018; Wikipedia 2018e). This principle is presented in Figure 1 I\&FAM Basic Conceptual Model below.

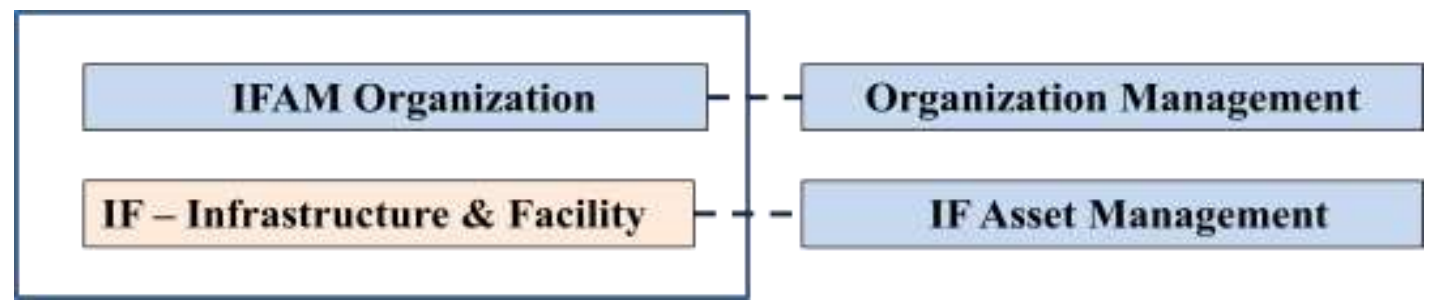

Figure 1 I\&FAM Basic Conceptual Model

What is I\&FAM - Knowledge Basic Structure

Based on the above Basic Conceptual Model, the I\&FAM Basic Knowledge Structure, here, is gouped into 5 components : the above 4 components and the Tools for Analysis knowledge (Fabry 2003; Soemitro \& Suprayitno 2018 \& Suprayitno \& Soemitro 2018). This Knowledge Basic Structure is presented in Figure 2 below.

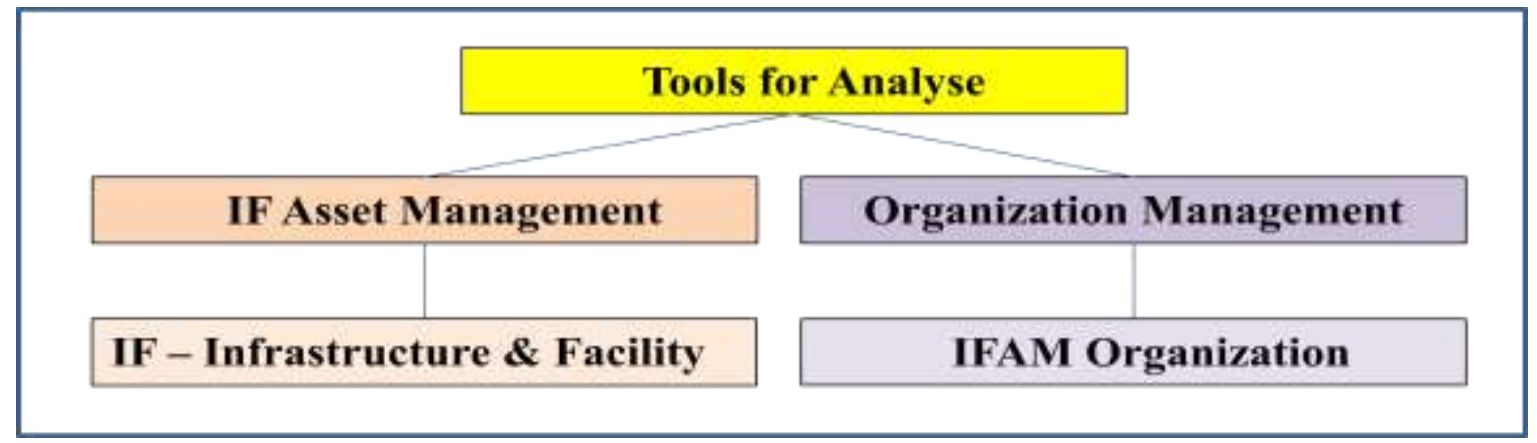

Figure 2 IFAM Knowledges Basic Structure

What is Infrastructure \& Facility - Basic Knowledge

I\&F Basic Knowledges consists of : family, type, class, function, physical form and structure, supply-demand characteritics, operational mechanism and characteristics, deterioration and maintenance charcteristics, financial \& economic characteritics, related existing regulation, spatial aspects and environmental aspects (Soemitro \& Suprayitno 2018; Suprayitno \& Soemitro 2018; Wikipedia 2018a; Wikipedia 2018d). This Basic Knowledge of I\&F is presented in Figure 3 below. 


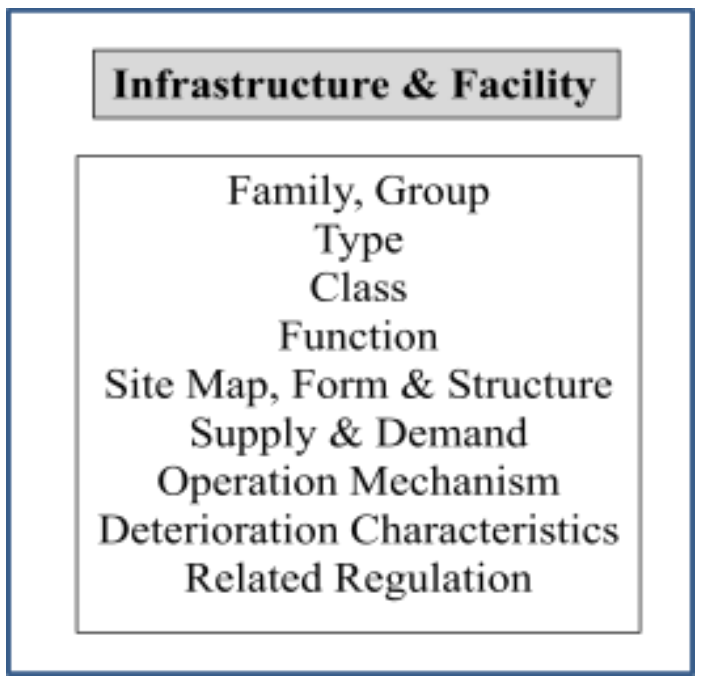

Figure 3 I\&F Basic Knowledge

What is I\&FAM Managing Organization - Basic Konowledge

The I\&F Managing Organization Basic Knowledge consists of the following knowledge components : public/private family, type, class, function, structure, task, reporting to, resouces characteritics, organization behaviour, risk characteritics, related regulation (Groth 2013; Nadler, Tushman \& Hatvany 2001). The I\&F Managing Organization Basic Knowledge are presented in the following Figure 4.

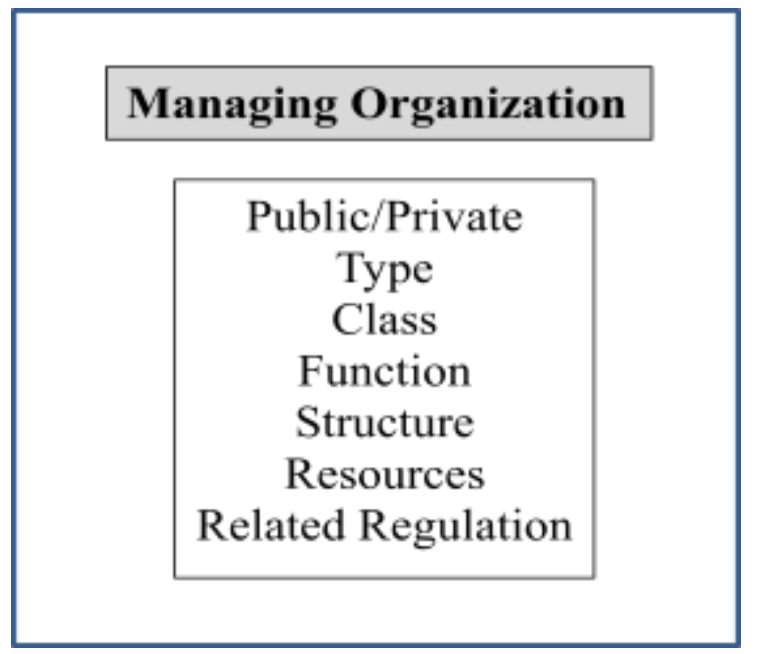

Figure 4 I\&F Managing Organization Basic Knowledge

What is I\&F Asset Management - Basic Knowledge

Basicaly, the Basic Knowledge of I\&F Asset Management for different I\&F lies on the following Basic I\&FAM Steps : policy, idea, planning, design, construction, administration \& certification, operation \& maintennce, disposal, evaluation. The whole I\&FAM must respect the existing related regulation, the spatial aspects, and the environmental aspects. Different I\&F generate different value and different pertinence of the parameters and variables. The I\&FAM knowledge is not about I\&F Engineering knowledge (Soemitro \& Suprayitno 2018; Suprayitno \& Soemitro 2018; Wikipedia 2018; Wikipedia 2018e). The I\&FAM Basic Knowledge is presented in Figure 5 below. 


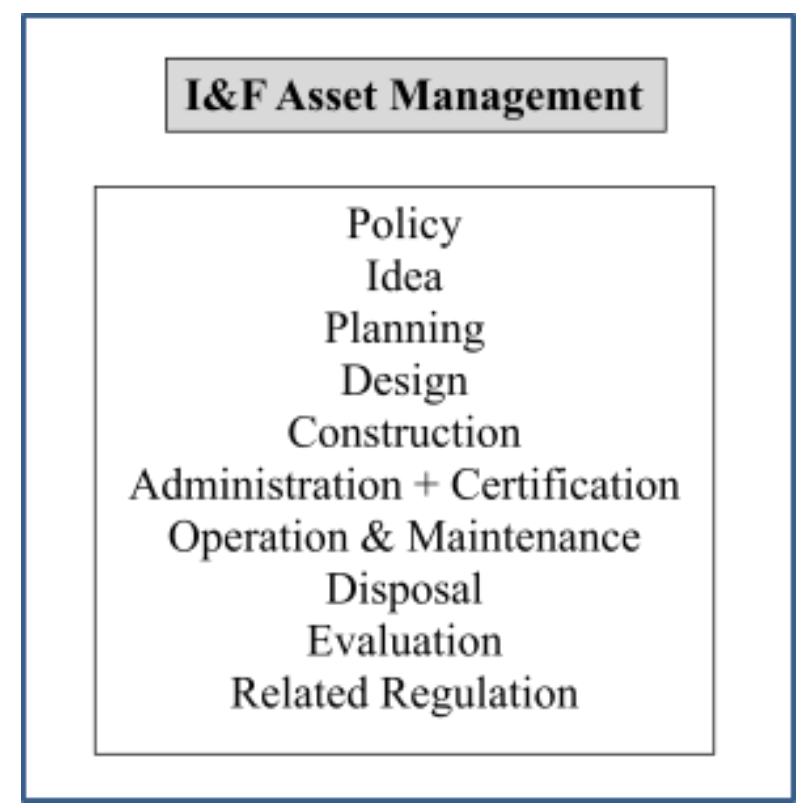

Figure 5 I\&F Asset Management Basic Knowledge

What is the IFAM Organization Management - Basic Knowledge

The Basic Knowledge of Organization Management consists of knowledge on : the POAC principle, HR management, financial management, risk management, SOP, administrative filing, organization behavior, SIM, management science, and related regulations (Doney 2017; Fabry 2003; Groth 2013; Timms 2012). The Organization Management Basic Knowledge is presented in Figure 6 below.

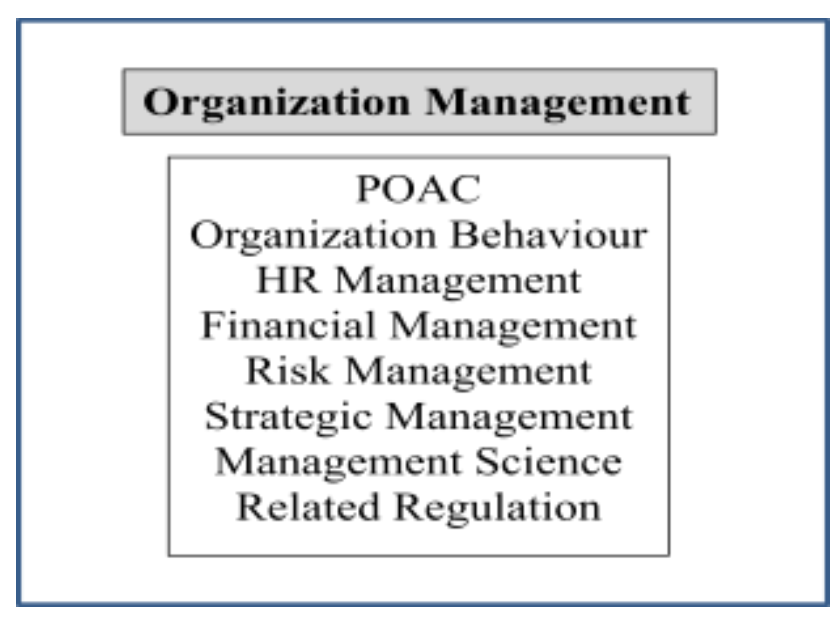

Figure 6 Organization Management Basic Knowledge

What is Tools for Analyse - Basic Knowledge

Analyse in I\&FAM consist of the following tasks : analyse, evaluation, decision making. These tasks need knowledge on Tools for Analyse, which is basicaly consists of decision making techniques, concept mapping, quantitatve model, qualitative model, mathematical modelling, statistics technique (Doney 2017; Fabry 2003; Klockers \& Willeke 2001; Krueger 2001; Oxenburgh \& Marlpow 2005; Peersman 2014; Timms 2012; Zdenka, Petr \& Radek 2011). The Basic Knowledges on Tools for Analyse is presented in Figure 7 below. 


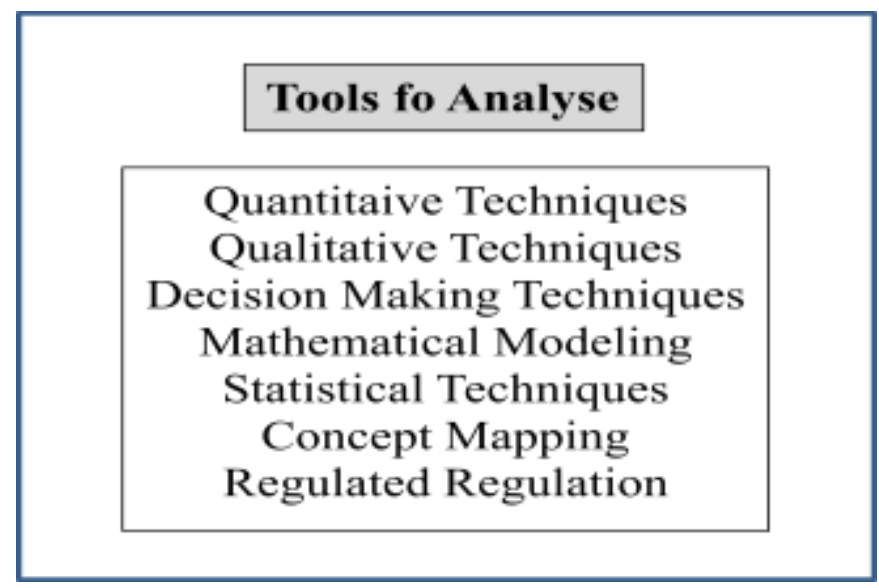

Figure 7 Tools for Analysis Basic Knowledge

What are Computer Aided Software can be used for I\&FAM - Basic Knowledges

Several Compoture Aided Software can be identified. They are, among others are : spread sheet program, data base software, geographical information system software, operation research software, concept mapping software, project management software, decision making software, mathematical modeling software; asset management software. Each type of software exists in several, so the various names of the software are not mentioned here. (Elmasri \& Navathe 2010; ESRI 2012; Leblanc \& Grossman 2008; Munuzuri \& Gonzalez-Filiu 2013; Nhat-Minh \& Swostik 2014; Oxenburgh \& Marlow 2005; Oyediran 2016; Sage 2013; Saltzman \& Margot 2007). The Computer Aided Software Basic Knowledge is presented in Figure 8 below.

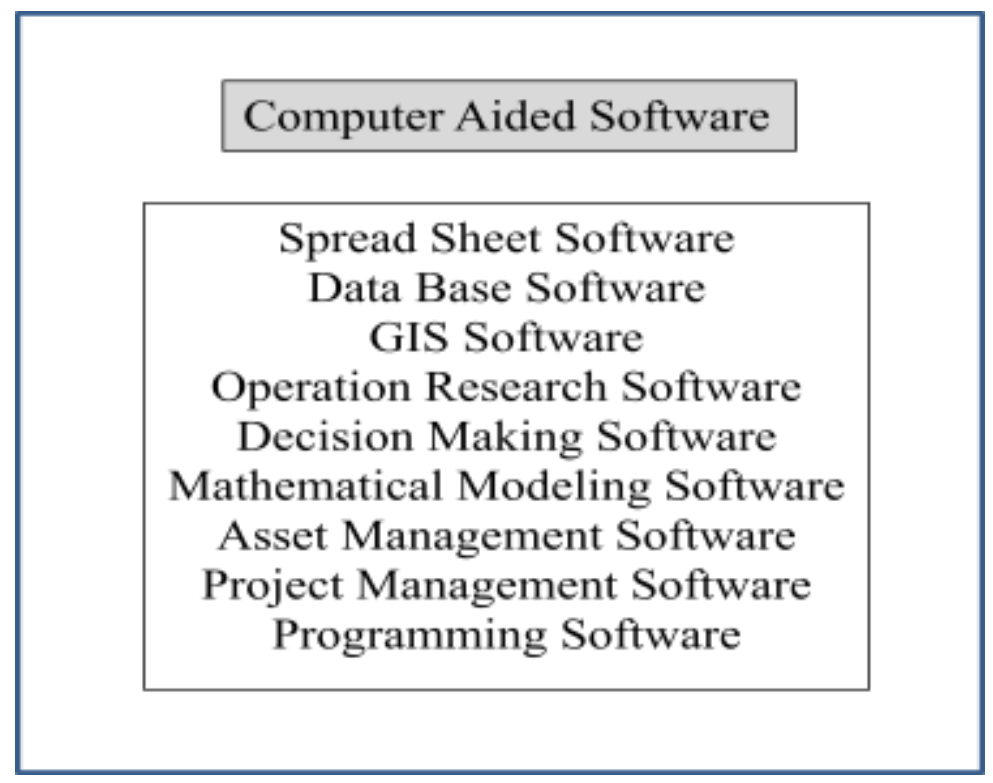

Figure 8 Computer Aided Software Basic Knowledge

\section{CONCLUSIONS}

The research has been finished, the objective has been attained. The research formulated that the I\&FAM Knowledges Development Framework, for the shake of clarity and easiness could be grouped into 8 different groupes of knowledges, as follows :

- I\&FAM Conceptual Model

- I\&FAM Framework for Knowledge Development

- I\&F Basic Knoweledge 
- I\&F Managing Organization Basic Knowledge

- I\&F Asset Management Basic Knowledge

- Organization Management Basic Knowledge

- Tools for Analysis Basic Knowledge

- Computer Aided Tools Basic Knowledge

This Framework is merely a proposal and needs to be critized and corrected if necessary. A certain lack or error in Framework formulation can be detected only by using it.

This Framework still need to be developed, mainly by confronting this concept against the reality by using it and to be updated step by step. Further, deeper and more complete analyse by blocks of knowledge need to be developed soon afterward.

Notes. This paper is the first basic preparation toward developing the I\&FAM Knowledge. This is merely a Knowledge Development proposal, which should be used, critized and improved in order to get a better Framework. This paper is designated to be written and published in JMAIF.

\section{REFERENCES}

Doney, Jim (2017). "Strategic Analysis Tools". Topic Gateway Series No. 34. CIMA - The Chartered Institute of Management Accountants. London.

Elmasri, R. \& Navathe, S.B. (2010). Fundamentals of Database System. Sixth Edition. AddisonWesley. Boston.

Eppler, M.J. (2006). "A comparaison between concept maps, mind maps, conceptual diagrams, and visual metaphors as complementary tools for knowledge construction and sharing". Information Visualization (2006) 5, 202-210.

ESRI (2012). What is GIS. ESRI, Redland.

Fabry, Jan (2003). Management Science. Faculty of Informatics and Statistic. University of Economics Prague. Prague.

FacDev (2010). "Concept Mapping”. Lecture Notes. Faculty Development and Instructional Design Center. Northern Illinois University.

Groth, Lars (2013). Overview of Theories on Management and Organization. Institutt for Informatikk. University of Oslo. Oslo.

Klockers, H-J \& Willeke, C. (2001). Monetary Analysis : Tools and Applications. European Central Bank. Frankfurt am Main.

Krueger, Richard A., et al (2001). Social Analysis - Selected Tools and Techniques. Social Development Department, The World Bank. Washington D.C.

Learning Support (2010). "Mind Mapping". Lecture Notes. Otago Polytechnic. Dunedin.

Leblanc, L.J. \& Grossman, T.A. (2008). "Introduction: The Use of Spreadsheet Software in the Application of Management Science and Operation Research”. Interface, Vol. 38, No. 4, July-August 2008, pp. : 225-227.

Munuzuri, J. \& Gonzalez-Feliu, J. (2013). "Decision Making Tools and Procedures for City Logistics - An Introduction to the Special Issue on Decision Support for Urban Logistics". European Transport, (Year) Issue 54, Paper no. 1.

Nadler, D.A., Tushman, M.L. \& Hatvany, N.G. (2001). Managing Organizations, Readings and Cases. Little, Brown and Company. Boston.

Nhat-Minh, H. \& Swostik, S. (2014). Project Management Software and Its Utilities. Lahti Universities of Applied Science. Lahti.

Oxenburgh, M \& Marlow, P. (2005). "The Productivity Assessment Tools : Computer-based cost benefit analysis model for the economic assessment of occupational health and safety interventions on worksplace". Journal of Safety Research - ECON proceedings 36 (2005) 209-214. 
Oyediran, O.B. (2016). "Mathematical Modelling and Simulation and Applications". Workshop on COMSOL Software held at NMC, 31 st July - 6th August 2016. Abuja

Peersman, G. (2014). Overview : Data Collection and Analyse Methods in Impact Evaluation. Methodological Briefs, Impact Evaluation No. 10. UNICEF Office of Research. Florence.

Soemitro, R.A.A. \& Suprayitno, H. (2018). "Pemikiran Awal mengenai Konsep Dasar Manajemen Aset Fasilitas”. Jurnal Manajemen Aset Infrastruktur \& Fasilitas, Vol. 2, Sup. 1, Juni 2018, hal : 1-13.

Sage (2013). Fixed Asset Management - What you need to know. Sage Incorporation. London.

Saltzman, M. \& Margot, F. (2007). "COIN-OR : Open-Source Software for Operation Research - A Status Report. International Ssientific Committe for Tuna and Tuna Like Species in the North Pacific Ocean 2007 (ISC07), Plenary Session, 25-30 July 2007. Busan.

Suprayitno, H. \& Soemitro, R.A.A. (2018). "Preliminary Reflexion on Basic Principle of Infrastructure Asset Management". Jurnal Manajemen Aset Infrastruktur \& Fasilitas, Vol. 2, No. 1, Maret 2018, hal : 1-9.

Suprayitno, H. \& Tangahu, B.V. (2018). "Formulating a Policy for Developing Regional Solid Waste Final Disposal Installation in East Java Province". Jurnal Manajemen Aset Infrastruktur \& Fasilitas, Vol. 2, Sup. 1, Juni 2018, hal : 15-25.

Timms, J. (2012). Introduction to Bussines and Management. The London School of Economics and Political Science. University of London. London.

Wikipedia (2018). "Asset Management". http://en.wikipedia.org/wiki/Assett_management, accessed 14 August 2018, 10:13 WIB.

Wikipedia (2018a). "Infrastructure". http://en.wikipedia.org/wiki/Infrastructure. downloaded 19 August 2018, 15:35.

Wikipedia (2018b). "Framework". http://en.wikipedia.org/wiki/Framework. printed 23 August 2018, 05:15.

Wikipedia (2018c). "Software Framework". http://en.wikipedia.org/wiki/Software Framework. printed 23 August 2018, 05:25.

Wikipedia (2018d). "Facility". http://en.wikipedia.org/wiki/Facility. printed 26 August 2018, 07:32.

Wikipedia (2018e). "Facility Management". http://en.wikipedia.org/wiki/Facility_Management. printed 26 August 2018, 07:36.

Zdenka, P., Petr, S. \& Radek, S. (2011). "Data Analysis : tools and methods". Recent Research in Automatic Control, January 2011, pp. 201-206. 